\title{
ALIGNING IT WITH BUSINESS MODEL TO PERFORM ORGANIZATIONAL CAPABILITIES IN ACHIEVING BUSINESS PERFORMANCE
}

\author{
Edhi Juwono, Harjanto Prabowo, Dyah Budihastuti and Ford Lumban Gaol \\ Bina Nusantara University, Jakarta, Indonesia
}

Received 2014-11-07; Revised 2014-11-12; Accepted 2014-12-30

\begin{abstract}
Information Technology (IT) is becoming an important driver for organization to perfom an organizational capability. Even IT is an importan driver, it is not the only one. IT should be aligned with business model to perform a organizational capabilities in achieving business performance.
\end{abstract}

Keywords: Business Model, Information Technology, Organization Capability, Business Performance

\section{INTRODUCTION}

According to Bank Indonesia (The Central Bank of Indonesia), there are 120 banks in Indonesia http://www.bi.go.id/en/publikasi/laporan-keuangan/alamatbank/umum/Default.aspx (visit January 15, 2015). The 120 banks are classified in five types as can be seen in Table $\mathbf{1}$.

Based on internal source of Perbanas (Indonesian's National Banks Association), it is found that only 110 banks are members of Perbanas since 10 banks are foreign banks. The member of Perbanas is classified based on minimum capital requirement: There are 60 national banks with Minimum Capital Requirements (MCR) of less than IDR 1 billion, 35 banks with MCR of IDR 1 billion to less than IDR 5 billion, 11 banks with MCR of IDR 5 billion to less than IDR 30 billion and 4 banks with MCR of IDR 30 billion to more than IDR 30 billion.

Table 1. Type of bank in Indonesia

\begin{tabular}{lc}
\hline Type of bank & Number of banks \\
\hline Foreign Bank & 10 \\
Venture Bank (Domestic and foreign) & 15 \\
Regional Development Bank & 26 \\
(Owned by Local Authority) & \\
Foreign Exchange Bank & 39 \\
Non-Foreign Exchange Bank & 30 \\
Total & 120
\end{tabular}

In the short coming future, Indonesia and 9 other countries was committed to create ASEAN Economic Community (AEC) and it will transform ASEAN into a region with free movement of goods, services, investment and skilled labor and freer flow of capital (Asian Development Bank 2013). To support AEC, ASEAN needs to integrate its financial sector. In 2011, the ASEAN Central Bank Governors adopted the ASEAN Financial Integration Framework (AFIF) to provide a general approach to the liberalization and integration initiatives under the AEC. The AFIF aims to have a semiintegrated financial market by 2020 (ASEAN, 2014). Since banking industry is one of IT based industry, it will be very interesting to explore the readiness of banking sectors-in terms of business model and its IT in facing the semi-integrated financial market by 2020 .

Specifically, this study will be directed to reveal the alignment between business model and IT since information Technology (IT)-Business alignment has been consistently ranked at the top among other contemporary IT related top management concerns; in 2008 it was ranked on the first place (Bayzidnejad et al., 2012). In other words, IT needs to support the bank's business growth and customer needs (Ikatan Bankir Indonesia, 2014). Moreover, IT is expected to transform the business model (Applegate et al., 2009). Since Bayzidnejad et al. (2012) draw our attention on how IT was aligned to

Corresponding Author:Edhi Juwono, Bina Nusantara University, Jakarta, Indonesia 
business in the banking industry of Iran, it encouraged the same curiosity to apply it in Indonesian banking industry.

\section{LITERATURES REVIEW}

\subsection{Business Performance}

What ever, the activities of the business, finally we come to see the result and the results are represented by the business performance. Since long ago people believe that performance is the end result of business activity (Hunger and Wheelen, 1997). When we talk about business performance, it has to be taken to the area of strategic management. There are three stages in strategic management, i.e., strategy formulation, strategy implementation and strategy evaluation (David, 2013) and in last stage we will come to organizational performance or business performance. One of the studies which relates Information Technology (IT) to business performance is written by Croteau and Raymond (2004). They were using Henderson and Venkatraman (1999) in measuring the business performance. So far it has not been found other publication, which relates organizational capability to organizational performance or business performance.

\subsubsection{Organizational Capabilities}

Although some studies put IT in relation with organizational performance or business performance (Croteau and Raymond, 2004; Chung et al., 2005; Zhang and Tansuhaj, 2007) there are studies concerning organizational capability and performance (Lu, 2006; Tuan and Yoshi, 2010; Benitez-Armando and Walczuch 2012). It was found that executives faced two key organizational design challenges as they attempted to design organizations and build capabilities (Applegate et al., 2009). They put IT as an enabler to cope with the challenges-i.e., (1) agility and control and (2) accountability and collaboration. So it can be concluded that organizational capabilities deals with two dimensions: First is agility and control and the second one is accountability and collaboration.

\subsubsection{Information Technology}

Using Henderson and Venkatraman (1999) Strategic Alignment Model, IT can be seen as a variable with two dimensions: (1) IT Strategy (technology scope, systemic competencies and IT governance) and (2) IT Infrastructure and Processes (architecture, processes and skills).

\subsubsection{Business Model}

So far it cannot be found the study about business model and organizational capabilities, but since strategic management stages consist of strategy formulation, strategy implementation and strategy evaluation (David, 2013), it is considered that business model is done in strategy formulation and organizational capabilities is done in strategy implementation and business performance is done in strategy evaluation. According to Applegate et al. (2009) there are two dimensions of business model, i.e., strategy and capabilities (to execute strategy).

\subsubsection{Aligning Competencies}

Croteau and Raymond (2004) using the definition of fit as covariation (Venkatraman, 1989) proposed a research model that put competencies alignment as the covariation between strategic and IT competencies. Inspired by Croteau and Raymond (2004), this research proposed a concept of alignment competency in a sense of a competency to develop and implement IT aligned with the business model to perform organizational capabilities.

\section{PROBLEM INDENTIFICATION AND STATEMENTS}

To cope with new challenges driven by the semiintegrated financial market by 2020, the aroused problems will be the business performance of the banks. The business performance will be solved by the banks' organizational capability and the organizational capability will be affected by banks' business model, its IT and its aligned competency. Therefore, the research questions will be: (a) is there any relationship between IT and alignment competency? (b) Is there any relationship between business model and alignment competency? (c) Is there any relationship between IT and business model? (d) Does IT impact on organizational capability? (e) Does business model impact on organizational capability? (f) Does alignment competency impact on organizational capability? (g) Does organizational capability impact on business performance?

\section{THEORETICAL FRAMEWORK}

Based on the literature review, the theoretical framework can be described as shown in the Fig. 1 . 


\section{HYPOTHESES AND PROPOSED RESEARCH MODEL}

Based on the theoretical framework, it can be proposed 7 hypotheses as follows:

H-1: There is a relationship between IT and organizational capability.

$\mathrm{H}-2$ : There is a relationship between business model and organizational capability.
H-3: There is a relationship between IT and business model.

H-4: IT impacts on organizational capabilities.

H-5: Business strategy impacts on organizational capabilities.

H-6: The Alignment capability impacts on organizational capabilities.

H-7: Organizational capabilities impacts on business performance.

All of the hypotheses can be described in the proposed research model that can be seen in the Fig. 2 .

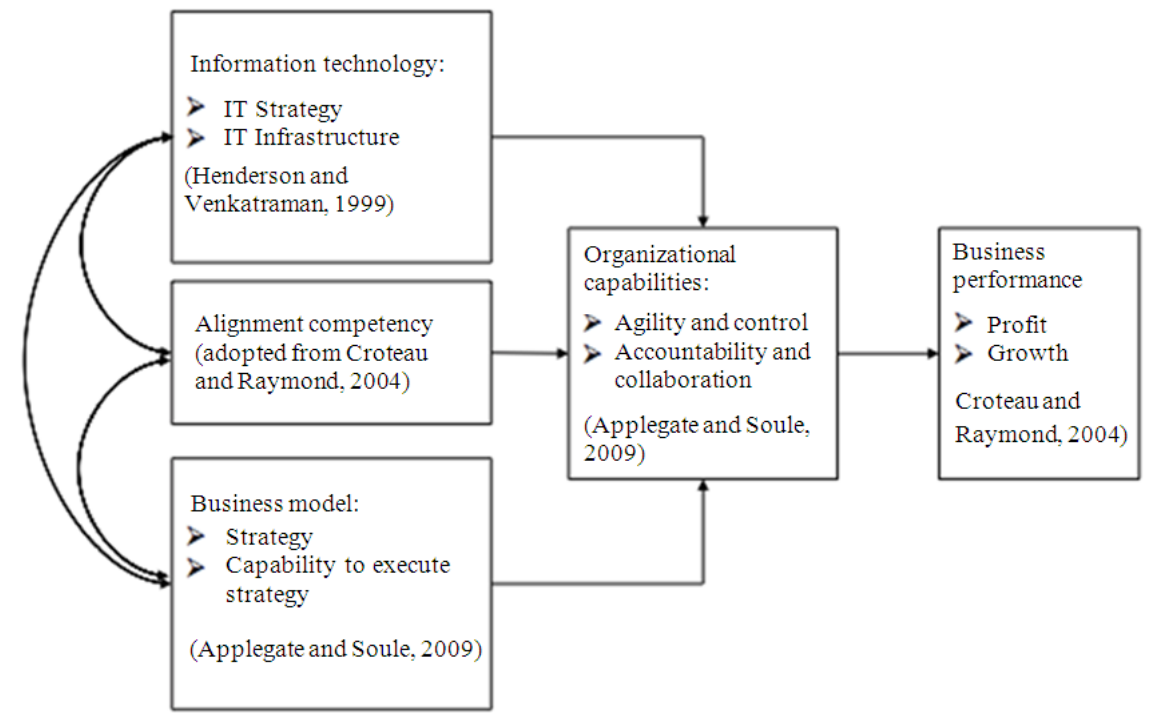

Fig. 1. Theoretical Framework

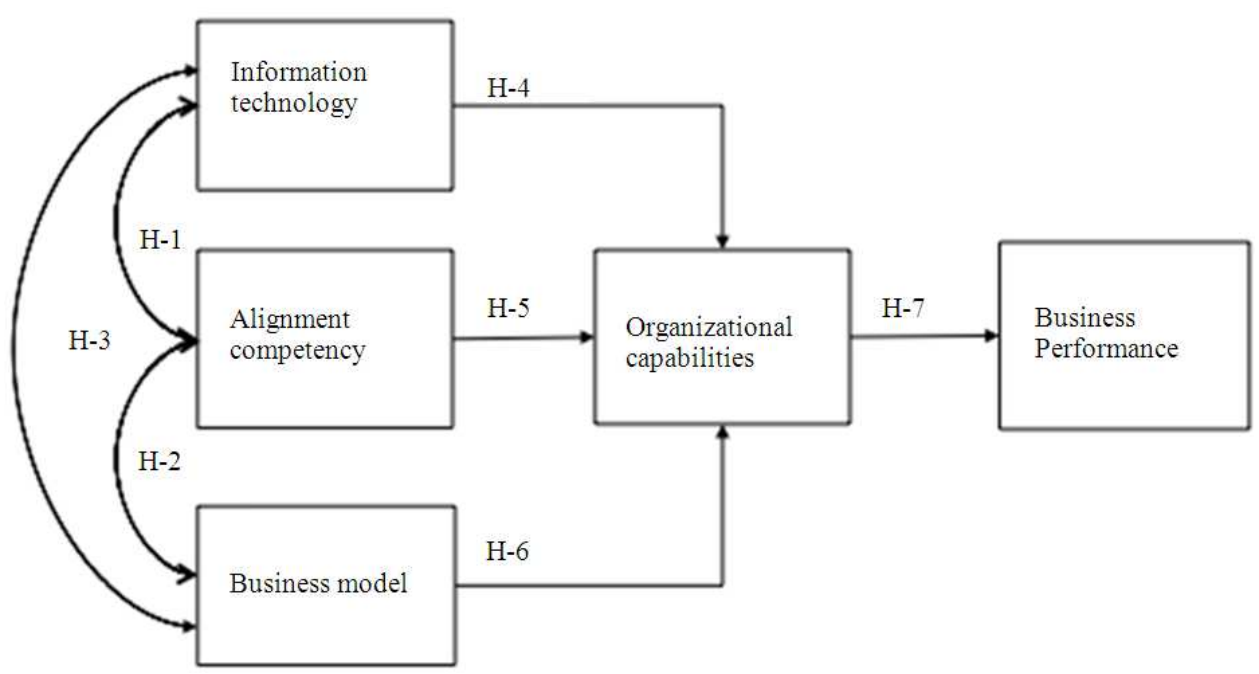

Fig. 2. Proposed Research Model 


\section{CONCLUSION}

This paper propose the conceptual analysis of the relationships between IT and business model. Since IT is not directly align with the business model, we propose an alignment competency as part of organizational competency to make sure that IT is becoming blended with the business model to perform an expected business performance.

\section{ACKNOWLEDGEMENT}

We would like to thank to the board and staff member of Doctorate Program of Resesarch in Management, Bina Nusantara University; without their support this article would not have been possible.

A special thank to the reviewers and the executive editors who let this article is becoming part of their publication.

\section{ADDITIONAL INFORMATION}

\subsection{Funding Information}

This conceptual study cannot be completed without funding and support from Doctorate Program, Bina Nusantara through its library.

\subsection{Author's Contributions}

Edhi Juwono: Preparation and developing the manuscript.

Harjanto Prabowo: Reviewing the literature review and theoretical framework

Dyah Budihastuti: Reviewing the hypotheses and research model.

Ford Lumban Gaol: Reviewing all of the manuscript to be proper for a publication.

\subsection{Ethics}

Any ethical issues that may arise after the publication of this manuscript will be under the responsible of the authors.

\section{REFERENCES}

Applegate, L.M., R.D. Austin and D.L. Soule, 2009. Corporate Information Strategy and Management. 8th Edn., McGraw-Hill, Boston, ISBN-10: 0071263195, pp: 513.

ASEAN, 2014. ASEAN Economic Community (AEC) 2015: Financial Integration in ASEAN. ASEAN.
Bayzidnejad, M., P. Kafche and R. Shafeai, 2012. Alignment of IT with business strategy in the banking industry of Iran. Interdiciplinary J. Contemporary Res. Bus., 4: 391-410

Benitez-Armando, Jose and Walczuch, Rita M. 2012. Informatio Technology, the Organizational Capability of Proactive Corporate Environmental Strategy and Firm Performance: A Resource-Based Analysis. Eur. J. Inform. Syst., 21: 664-679.

Chung, S.H., T.A. Byrd, B.R. Lewis and F.N. Ford, 2005. An empirical study of the relationships between IT infrastructure flexibility, mass customization and business performance. Database Adv. Inform. Syst., 36: 26-44. DOI: $10.1145 / 1080390.1080394$

Croteau, A.M. and L. Raymond, 2004. Performance outcomes of strategic and IT competencies alignment. J. Inform. Technol., 19: 178-190. DOI: $10.1057 /$ palgrave.jit.2000020

David, F.R., 2013. Strategic Management: Concepts and Cases. 13th Edn., Prentice Hall, Boston, ISBN-10: 0273767488, pp: 688.

Henderson, J.C. and N. Venkatraman, 1999, Strategic alignment: Leveraging information technology for transforming organizations. IBM Syst. J., 38: 472-784. DOI: 10.1147/SJ.1999.5387096

http://www.bi.go.id/en/publikasi/laporan-keuangan/alamatbank/umum/Default.aspx

Hunger, D.J. and T.L. Wheelen, 1997. Essentials of Strategic Management. Reading: Addison-Wesley.

Ikatan Bankir Indonesia. 2014. Strategi Sukses Bisnis Bank: Modul Sertifikasi Tingkat III General Banking. Jakarta, Gramedia Pustaka Utama.

Lu, Y., 2006. IT capability, uncertainty and organizational performance: Development of measures and empirical examination. Ph.D. Thesis, University of Wisconsin-Milwaukee.

Tuan, N.P. and T. Yoshi, 2010. Organizational capabilities, competitive advantage and performance in supporting industries in Vietnam. Asian Acad. Manage. J., 15: 1-21.

Venkatraman, N., 1989. The concept of fit in strategy research: Toward verbal and statistical correspondence. Acad. Manage. Review, 14: 423-444. DOI: 10.5465/AMR.1989.4279078

Zhang, M. and P.S. Tansuhaj, 2007. Organizational Culture, Information Technology Capability and Performance: The Case of Born Global Firm. Multinational Bus. Rev., 15: 43-78. DOI: $10.1108 / 1525383 X 200700012$ 